\title{
Analisis Profil Kemampuan Berpikir Kritis Mahasiswa PGSD Dengan Graded Response Models Pada Pembelajaran IPA
}

\author{
Tri Wiyoko ${ }^{1}$ \\ 1.Program Studi PGSD STKIP Muhammadiyah Muara Bungo \\ Coressponding Author. E-mail: \\ 1yokostkipmb@gmail.com
}

Received: 22 Juni 2018

Accepted: 1 Desember 2018 Online Published: 13 Januari 2019

\begin{abstract}
Abstrak
Penelitian ini bertujuan untuk menganalisis profil kemampuan berpikir kritis mahasiswa PGSD dengan menggunakan graded response models pada pembelajaran IPA. Indikator berpikir kritis yang dijadikan acuan dalam penelitian ini menurut Peter A, Facione antara lain: interpretasi, analisis, eksplanasi, inferensi, evaluasi, dan regulasi diri. Penelitian yang dilaksanakan termasuk jenis penelitian kualitatif dengan pendekatan deskriptif. Subjek penelitian Mahasiswa semester II PGSD STKIP Muhammadiyah Muara Bungo sebanyak 86 Mahasiswa tahun akademik 2017/2018. Hasil penelitian menunjukkan bahwa kemampuan berpikir kritis Mahasiswa dengan tingkat rata-rata (sedang) sebesar 48,8\%, kemudian dengan kriteria rendah 26,7\%. Kriteria sangat tinggi sebesar 4,6\%, tinggi 11,6\% dan berkriteria rendah sebesar 8,1\%. Kemampuan berpikir kritis mahasiswa PGSD untuk indikator tertinggi yaitu regulasi diri sebesar 68,60\% dengan kategori tinggi, indikator analisis sebesar 66,30\% dengan kategori tinggi, indikator penjelasan sebesar 55,20\% dengan sedang, Indikator interpretasi sebesar 30,50\% dengan kategori rendah, aspek evaluasi sebesar 30,20\% dengan kategori rendah dan indikator inferensi sebesar 26,20\% dengan kategori rendah.
\end{abstract}

Kata Kunci: Berpikir kritis, Graded Response Models..

\section{Analysis Of Capability Profile Of Critical Thinking Of PGSD Students With Graded Response On Science Learning}

\begin{abstract}
This research is aimed to analyze the profile of critical thinking skill profile of primary school teacher education students with graded response models (grm) to science subject. The indicators of critical thinking used as a guidance in this research is according to peter a facione namely; interpretation, analysis, explanation, evaluation, and self-regulation. It belongs to a qualitative research with descriptive approach. The subject of the research is the second semester of primary school teacher education students in STKIP Mubammadiyah muara bango in amount of 86 students at the academic year 2017/2018.

The result of the research shows that the ability of students' critical thinking skill at the average level (middle) in amount of $48,8 \%$, low level $26,7 \%$. The bighest criteria is in amount of 4,6\%, bigh $11,6 \%$ and low $8,1 \%$. The ability of critical thinking skill of primary school teacher education students in term of highest indicator is on the self-regulation in amount of $68,60 \%$ with high category, analysis of indicator 66,30\% with high category, explaining indicator 55,20\% with average category, interpretation indicator 30,50\% with low category, evaluation aspect 30,20\% with low category and inference indicator $26,20 \%$ with low category.
\end{abstract}

Keywords: Critical Thinking, Graded Response Model 


\section{PENDAHULUAN}

Pendidikan merupakan modal untuk membangun sumber daya manusia (SDM) yang cerdas dan berbudi luhur. Manusia melalui pendidikan akan melahirkan tatanan lingkungan kehidupan yang baik. salah satunya dengan Ilmu Pengetahuan Alam (IPA). Perkembangan IPA tidak hanya ditandai oleh adanya kumpulan fakta saja, tetapi juga ditandai oleh munculnya metode ilmiah (scientific methods) yang terwujud melalui suatu rangkaian kerja ilmiah (working scientifically), nilai dan sikap ilmiah (scientific attitudes) Depdiknas (2007: 8).

Tujuan pembelajaran IPA secara tersirat menuntut untuk mengajarkan kemampuan berpikir. Kemampuan berpikir fakta dan informasi untuk membuat keputusan berperilaku (Dharma, 2008: 14). Proses berpikir berhubungan dengan cara bertindak yang memerlukan keterlibatan aktif pemikir melalui hubungan kompleks yang dikembangkan melalui kegiatan berpikir (Tawil dan Liliasari, 2013: 5). Oleh karena itu, pembelajaran IPA perlu menstimulasi mahasiswa untuk aktif dalam pembelajaran melalui proses eksplorasi sesuai kemampuan berpikir mahasiswa. Kemampuan berpikir adalah kemampuan di dalam menyatukan perilaku/tindakan, pengetahuan, dan kemampuan yang memungkinkan seseorang untuk membentuk lingkungannya menjadi efektif.

Salah satu keterampilan yang perlu dikembangkan dalam pembelajaran IPA adalah kemampuan berpikir (Rosana, 2012). Kemampuan berpikir dapat dibedakan menjadi berpikir kritis dan berpikir kreatif. Menurut Edward Glaser Angelo (1941:6) di dalam Alec Fisher, seseorang yang mempunyai keterampilan berpikir kritis dapat diidentifikasi dari perilaku yang diperlihatkannya yaitu; (1) mengenal masalah; (2) menemukan caracara yang dapat dipakai untuk mengatasi masalah; (3) mengumpulkan dan menyusun informasi; (4) mengenal asumsi-asumsi dan nilai-nilai yang tidak dinyatakan; (5) memahami dan menggunkan bahasa yang tepat, jelas dan khas; (6) menganalisis data; (7) menilai fakta dan mengevaluasi; (8) mengenal adanya hubungan logis antara masalah (9) menarik kesimpulan, Fisher (2008: 3). Menurut Peter A, Facione (2015: 9-10) dimensi skill berpikir kritis yaitu interpretasi, analisis, evaluasi, kesimpulan, penjelasan dan self-regulation. Berdasarkan beberapa pendapat di atas, indikator berpikir kritis yang digunakan pada penelitian ini antara lain: interpretasi, analisis, eksplanasi, inferensi, evaluasi, dan regulasi diri. Indikator tersebut sesuai dengan pendapat.

Kemampuan berpikir kritis sangat diperlukan oleh semua mahasiswa. Karena kemampuan berpikir sebagai salah satu kemampuan esensial yang berpengaruh langsung terhadap kesuksesan akademik dan profesional mahasiswa di masa yang akan datang (Quitadamo, 2008). Kemudian siswa yang memiliki kemampuan berpikir kritis akan memberikan pengaruh terhadap kemampuan menulis narasi. (Inggriyani, 2017: 105). Sehingga kemampuan berpikir kritis penting ditingkatkan dalam mempersiapkan peserta didik atau generasi penerus bangsa untuk menjadi pemikir-pemikir yang kritis, jujur dan bermartabat, serta mampu menghadapi berbagai tantangan dan dapat bertahan hidup secara manusiawi dengan penuh rasa percaya diri (Hasratuddin, 2010:20).

Mahasiswa PGSD STKIP Muhammadiyah Bungo berasal dari latar belakang pendidikan yang berbeda-beda. Sebagaimana gambar 1 .

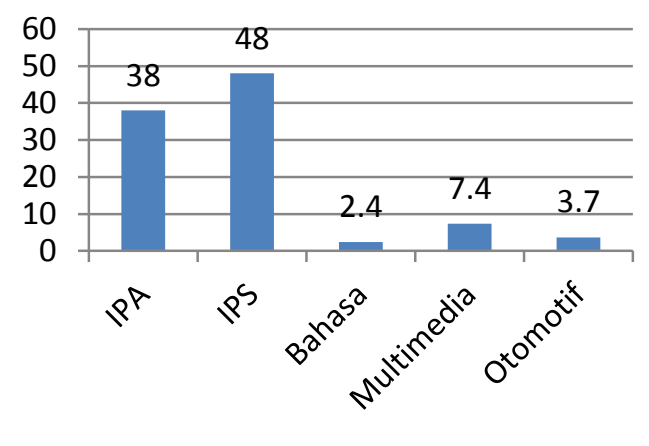

Gambar 1. Pendidikan Asal Mahasiswa PGSD STKIP-MB

Berdasarkan Grafik 1. Terdapat mahasiswa yang berasal dari kelompok eksakta maupun noneksakta. Mahasiswa PGSD STKIP-MB paling dominan berasal dari jurusan IPS sebesar $48 \%$, kemudian IPA 38\%, Multimedia 7,4\%, Otomotif $3,7 \%$ dan Bahasa 2,4\%. Walaupun berasal dari latar belakang jurusan pendidikan ditingkat SMA/Sederajat yang berbeda-beda. Akan tetapi mahasiswa PGSD telah menempuh mata kuliah konsep dasar IPA pada semester I. Sehingga dapat menjadi modal untuk mengikuti perkuliahan pembelajaran IPA SD di semester II. Mahasiswa akan semakin baik memiliki pemahaman dasardasar IPA, apabila dapat membiasakan berpikir 
kritis terhadap kejadian, fenomena dan peristiwa dalam kehidupan sehari-hari.

Pembiasaan berpikir kritis mahasiswa dapat dibangun dari proses pembelajaran di dalam kelas. Hal ini perlu dilakukan karena sebagai calon guru harus mampu mengajarkan kemampuan berpikir kritis kepada siswanya. Sejatinya kemampuan berpikir kritis merupakan keterampilan yang perlu dilatih sejak usia SD untuk membuat siswa terbiasa dengan cara berpikir yang akan menjadi modal belajar pada tingkat pendidikan berikutnya. Keterampilan berpikir tingkat tinggi juga membuat siswa mampu menyampaikan ide-ide argumentatif, logis, dan percaya diri, baik tertulis, lisan, dan tindakan. (Usmaedi, 2017: 82).

Kemampuan berpikir kritis merupakan elemen penting yang harus dimiliki Mahasiswa dalam Pembelajaran IPA SD. Oleh karena itu perlu untuk mengungkap kemampuan berpikir kritis mahasiswa pada pembelajaran IPA SD salah satunya dengan menggunakan Graded Response Models. Model Graded Response Models merupakan salah satu model IRT untuk memperkirakan kemampuan peserta tes dengan mempertimbangkan parameter peserta, tingkat kesulitan dan isi butir yang membedakan setiap masalah. (Wahyudi, 2016:1). Format tes yang diberikan ke mahasiswa dalam bentuk uraian dengan skoring model Graded Response Models. Hal ini dapat berguna untuk menilai bagaimana siswa mencapai dan menjelaskan kesimpulan mereka masing-masing (Quelmalz, 1985).

Berdasarkan uraian di atas, maka perlu adanya analisis profil kemampuan berpikir kritis mahasiswa PGSD dengan menggunakan graded response models pada pembelajaran IPA.

\section{METODE}

Penelitian yang dilaksanakan termasuk jenis penelitian kualitatif dengan pendekatan deskriptif. Penelitian dilaksanakan bulan Maret tahun akademik 2017/2018. Subjek penelitian mahasiswa semester II PGSD STKIP Muhammadiyah Muara Bungo sebanyak 86 Mahasiswa. Teknik sampling yang digunakan adalah purposive sampling.

Teknik pengumpulan data yang dilakukan dalam penelitian ini adalah teknik tes. Teknik tes dalam penelitian ini berupa tes tertulis dengan soal uraian. Skoring tes tertulis dalam penelitian ini dengan menggunakan Graded Response Models. Kemudian untuk mengkategorikan kriteria kemampuan berpikir kritis sesuai tabel 1 .

Tabel 1. Persentase Kriteria berpikir Kritis

\begin{tabular}{ll}
\hline \multicolumn{1}{c}{ Kriteria } & \multicolumn{1}{c}{ Persentase } \\
\hline Sangat tinggi & $80 \%<\mathrm{P} \leq 100 \%$ \\
Tinggi & $60 \%<\mathrm{P} \leq 80 \%$ \\
Rata-rata (sedang) & $40 \%<\mathrm{p} \leq 60 \%$ \\
Rendah & $20 \%<\mathrm{P} \leq 40 \%$ \\
Sangat rendah & $0 \%<\mathrm{P} \leq 20 \%$ \\
\hline
\end{tabular}

\section{HASIL DAN PEMBAHASAN}

Hasil penelitian yang telah dilaksanakan diperoleh data-data kemampuan berpikir kritis mahasiswa PGSD pada pembelajaran IPA. Data diperoleh dari tes tertulis soal uraian sebanyak 6 soal.

Tabel 2. Rekapitulasi Skor Tes Kemampuan Berpikir Kritis Mahasiswa

Pada Pembelajaran IPA SD

\begin{tabular}{|c|c|c|c|c|c|c|c|c|c|}
\hline \multirow{2}{*}{ Mahasiswa } & \multicolumn{6}{|c|}{ Skor Nilai Soal } & \multirow{2}{*}{$\begin{array}{l}\text { Total } \\
\text { Nilai }\end{array}$} & \multirow[b]{2}{*}{ Persetase } & \multirow[b]{2}{*}{ Kriteria } \\
\hline & 1 & 2 & 3 & 4 & 5 & 6 & & & \\
\hline PG1 & 1 & 1 & 0 & 2 & 2 & 1 & 7 & $29 \%$ & Rendah \\
\hline PG2 & 2 & 0 & 0 & 0 & 0 & 4 & 6 & $25 \%$ & Rendah \\
\hline PG3 & 1 & 4 & 0 & 2 & 3 & 4 & 14 & $58 \%$ & Rata-rata (sedang) \\
\hline PG4 & 0 & 3 & 3 & 4 & 3 & 3 & 16 & $66 \%$ & Tinggi \\
\hline PG5 & 0 & 4 & 0 & 0 & 2 & 3 & 9 & $37 \%$ & Rendah \\
\hline PG6 & 0 & 4 & 0 & 0 & 2 & 4 & 10 & $41 \%$ & Rata-rata (sedang) \\
\hline PG7 & 1 & 2 & 0 & 2 & 3 & 2 & 10 & $41 \%$ & Rata-rata (sedang) \\
\hline PG8 & 0 & 4 & 0 & 0 & 2 & 2 & 8 & $33 \%$ & Rendah \\
\hline PG9 & 4 & 3 & 4 & 2 & 4 & 4 & 21 & $87 \%$ & Sangat tinggi \\
\hline PG10 & 2 & 4 & 3 & 2 & 4 & 4 & 19 & $79 \%$ & Tinggi \\
\hline PG11 & 3 & 4 & 4 & 2 & 2 & 4 & 19 & $79 \%$ & Tinggi \\
\hline
\end{tabular}




\begin{tabular}{|c|c|c|c|c|c|c|c|c|}
\hline PG12 & 1 & 0 & & 2 & 2 & 9 & $37 \%$ & Rendah \\
\hline PG13 & 0 & 2 & 4 & 0 & 2 & 11 & $45 \%$ & Rata-rata (sedang) \\
\hline PG14 & 1 & 4 & 0 & 2 & 2 & 10 & $41 \%$ & Rata-rata (sedang) \\
\hline PG15 & 1 & 4 & 1 & 0 & 2 & 12 & $50 \%$ & Rata-rata (sedang) \\
\hline PG16 & 3 & 4 & 2 & 4 & 2 & 17 & $70 \%$ & Tinggi \\
\hline PG17 & 4 & 4 & 4 & 4 & 3 & 22 & $91 \%$ & Sangat tinggi \\
\hline PG18 & 0 & 2 & 4 & 0 & 3 & 13 & $54 \%$ & Rata-rata (sedang) \\
\hline PG19 & 1 & 4 & 0 & 2 & 3 & 13 & $54 \%$ & Rata-rata (sedang) \\
\hline PG20 & 1 & 4 & 0 & 2 & 1 & 10 & $41 \%$ & Rata-rata (sedang) \\
\hline PG21 & 1 & 3 & 0 & 0 & 2 & 10 & $41 \%$ & Rata-rata (sedang) \\
\hline PG22 & 0 & 4 & 0 & 2 & 3 & 13 & $54 \%$ & Rata-rata (sedang) \\
\hline PG22 & 0 & 0 & 0 & 0 & 2 & 2 & $8 \%$ & Sangat rendah \\
\hline PG23 & 1 & 3 & 0 & 2 & 3 & 11 & $45 \%$ & Rata-rata (sedang) \\
\hline PG24 & 0 & 2 & 3 & 0 & 0 & 9 & $37 \%$ & Rendah \\
\hline PG25 & 0 & 4 & 3 & 2 & 3 & 15 & $62 \%$ & Tinggi \\
\hline PG26 & 2 & 4 & 3 & 2 & 3 & 16 & $66 \%$ & Tinggi \\
\hline PG27 & 1 & 2 & 0 & 2 & 3 & 11 & $45 \%$ & Rata-rata (sedang) \\
\hline PG28 & 0 & 3 & 2 & 0 & 0 & 9 & $37 \%$ & Rendah \\
\hline PG29 & 1 & 3 & 0 & 2 & 4 & 12 & $50 \%$ & Rata-rata (sedang) \\
\hline PG30 & 0 & 4 & 0 & 0 & 0 & 4 & $16 \%$ & Sangat rendah \\
\hline PG31 & 2 & 4 & 0 & 2 & 1 & 11 & $45 \%$ & Rata-rata (sedang) \\
\hline PG32 & 0 & 4 & 0 & 2 & 2 & 9 & $37 \%$ & Rendah \\
\hline PG33 & 1 & 4 & 0 & 2 & 2 & 11 & $45 \%$ & Rata-rata (sedang) \\
\hline PG34 & 2 & 4 & 0 & 2 & 3 & 15 & $62 \%$ & Tinggi \\
\hline PG35 & 1 & 3 & 0 & 2 & 2 & 12 & $50 \%$ & Rata-rata (sedang) \\
\hline PG36 & 3 & 0 & 0 & 2 & 3 & 10 & $41 \%$ & Rata-rata (sedang) \\
\hline PG37 & 2 & 3 & 0 & 0 & 2 & 11 & $45 \%$ & Rata-rata (sedang) \\
\hline PG38 & 4 & 2 & 4 & 2 & 4 & 20 & $83 \%$ & Sangat tinggi \\
\hline PG39 & 2 & 2 & 2 & 0 & 3 & 13 & $54 \%$ & Rata-rata (sedang) \\
\hline PG40 & 2 & 4 & 4 & 0 & 2 & 16 & $66 \%$ & Tinggi \\
\hline PG41 & 3 & 3 & 2 & 1 & 4 & 17 & $70 \%$ & Tinggi \\
\hline PG42 & 3 & 2 & 2 & 0 & 2 & 12 & $50 \%$ & Rata-rata (sedang) \\
\hline PG43 & 2 & 2 & 0 & 2 & 3 & 11 & $45 \%$ & Rata-rata (sedang) \\
\hline PG44 & 0 & 4 & 0 & 2 & 3 & 12 & $50 \%$ & Rata-rata (sedang) \\
\hline PG45 & 0 & 0 & 0 & 0 & 2 & 4 & $16 \%$ & Sangat rendah \\
\hline PG46 & 2 & 4 & 0 & 4 & 2 & 14 & $58 \%$ & Rata-rata (sedang) \\
\hline PG47 & 3 & 4 & 0 & 2 & 2 & 15 & $62 \%$ & Tinggi \\
\hline PG48 & 2 & 4 & 0 & 0 & 2 & 11 & $45 \%$ & Rata-rata (sedang) \\
\hline PG49 & 3 & 4 & 4 & 2 & 2 & 17 & $70 \%$ & Tinggi \\
\hline PG50 & 2 & 3 & 0 & 0 & 1 & 10 & $41 \%$ & Rata-rata (sedang) \\
\hline PG51 & 2 & 4 & 0 & 0 & 2 & 11 & $45 \%$ & Rata-rata (sedang) \\
\hline PG52 & 1 & 1 & 2 & 0 & 2 & 6 & $25 \%$ & Rendah \\
\hline PG53 & 2 & 1 & 0 & 0 & 0 & 6 & $25 \%$ & Rendah \\
\hline PG54 & 2 & 4 & 0 & 0 & 2 & 11 & $45 \%$ & Rata-rata (sedang) \\
\hline PG55 & 2 & 0 & 4 & 2 & 3 & 14 & $58 \%$ & Rata-rata (sedang) \\
\hline PG56 & 2 & 0 & 0 & 0 & 2 & 8 & $33 \%$ & Rendah \\
\hline PG57 & 0 & 4 & 0 & 0 & 2 & 9 & $37 \%$ & Rendah \\
\hline PG58 & 2 & 2 & 0 & 0 & 3 & 10 & $41 \%$ & Rata-rata (sedang) \\
\hline PG59 & 1 & 2 & 0 & 0 & 1 & 6 & $25 \%$ & Rendah \\
\hline PG60 & 0 & 1 & 4 & 2 & 3 & 10 & $41 \%$ & Rata-rata (sedang) \\
\hline PG61 & 0 & 1 & 2 & 0 & 24 & 9 & $37 \%$ & Rendah \\
\hline PG62 & 2 & 3 & 4 & 2 & 3 & 15 & $62 \%$ & Tinggi \\
\hline PG63 & 1 & 1 & 4 & 0 & 22 & 10 & $41 \%$ & Rata-rata (sedang) \\
\hline
\end{tabular}




\begin{tabular}{llllllllll} 
PG64 & 2 & 3 & 0 & 0 & 2 & 0 & 7 & $29 \%$ & Rendah \\
PG65 & 0 & 0 & 0 & 0 & 1 & 4 & 5 & $20 \%$ & Sangat rendah \\
PG66 & 2 & 4 & 0 & 0 & 1 & 2 & 9 & $37 \%$ & Rendah \\
PG67 & 2 & 4 & 0 & 0 & 2 & 3 & 11 & $45 \%$ & Rata-rata (sedang) \\
PG68 & 3 & 2 & 0 & 2 & 2 & 4 & 13 & $54 \%$ & Rata-rata (sedang) \\
PG69 & 0 & 2 & 0 & 1 & 2 & 3 & 8 & $33 \%$ & Rendah \\
PG70 & 2 & 4 & 3 & 4 & 3 & 4 & 20 & $83 \%$ & Sangat tinggi \\
PG71 & 1 & 0 & 4 & 0 & 3 & 3 & 11 & $45 \%$ & Rata-rata (sedang) \\
PG72 & 0 & 3 & 0 & 0 & 2 & 4 & 9 & $37 \%$ & Rendah \\
PG73 & 2 & 1 & 4 & 0 & 2 & 1 & 10 & $41 \%$ & Rata-rata (sedang) \\
PG74 & 0 & 2 & 3 & 0 & 3 & 0 & 8 & $33 \%$ & Rendah \\
PG75 & 0 & 3 & 4 & 2 & 2 & & 11 & $45 \%$ & Rata-rata (sedang) \\
PG76 & 2 & 4 & 0 & 4 & 4 & 3 & 17 & $70 \%$ & Tinggi \\
PG77 & 0 & 4 & 0 & 0 & 3 & 4 & 11 & $45 \%$ & Rata-rata (sedang) \\
PG78 & 0 & 2 & 0 & 0 & 2 & 4 & 8 & $33 \%$ & Rendah \\
PG79 & 0 & 0 & 0 & 0 & 0 & 4 & 4 & $16 \%$ & Sangat rendah \\
PG80 & 0 & 4 & 4 & 0 & 2 & 4 & 14 & $58 \%$ & Rata-rata (sedang) \\
PG81 & 0 & 4 & 4 & 0 & 2 & 2 & 12 & $50 \%$ & Rata-rata (sedang) \\
PG82 & 1 & 1 & 0 & 0 & 4 & 0 & 6 & $25 \%$ & Rendah \\
PG83 & 0 & 3 & 0 & 0 & 3 & 3 & 9 & $37 \%$ & Rendah \\
PG84 & 0 & 1 & 0 & 0 & 0 & 0 & 1 & $4,1 \%$ & Sangat rendah \\
PG85 & 0 & 0 & 0 & 0 & 1 & 4 & 5 & $20 \%$ & Sangat rendah \\
PG86 & 1 & 1 & 0 & 2 & 2 & 1 & 7 & $29 \%$ & Rendah \\
\hline
\end{tabular}

Berdasarkan tabeL 2 Mahasiswa yang memiliki kemampuan berpikir kritis pada pembelajaran IPA SD dengan kriteria sangat tinggi sebanyak 4 orang, tinggi 10 orang, ratarata (sedang) 42 orang, rendah 23 orang dan sangat rendah 7 orang.

Hasil persentase menunjukkan bahwa mahasiswa PGSD dari kelas A dan B memiliki kemampuan berpikir kritis dengan skala rata-rata (sedang) sebesar 48,8\%, kemudian kamampuan berpikir kritis dengan kriteria rendah $26,7 \%$. Selanjutnya mahasiswa yang memiliki kemampuan berpikir kritis sangat tinggi sebesar $4,6 \%$, tinggi $11,6 \%$. Sedangkan yang berkriteria sangat rendah hanya $8,1 \%$.

Hasil analisis kemampuan berpikir kritis mahasiswa PGSD yang terdiri dari enam indikator yaitu interpretasi, analisis, evaluasi, inferensi, penjelasan dan regulasi diri tersajikan pada gambar 2 .

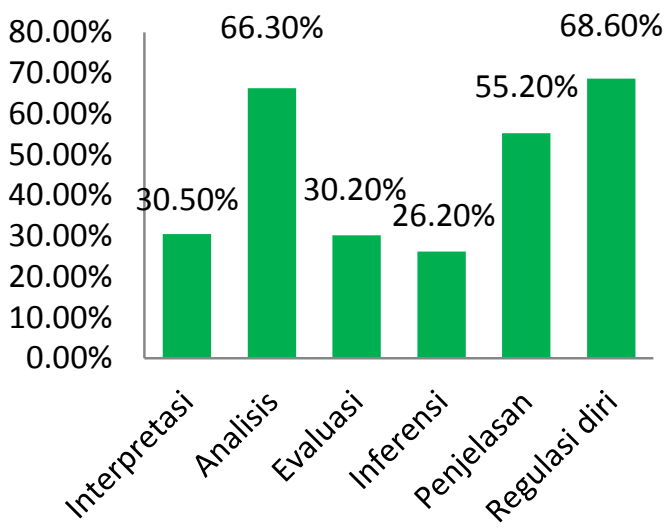

Gambar 2. Persentase Aspek Berpikir Kritis

Berdasarkan gambar 2, aspek kemampuan berpikir kritis mahasiswa tertinggi yaitu indikator regulasi diri (kesadaran diri) sendiri untuk memantau aktivitas kognitif sebesar 68,60\% dengan kategori tinggi, indikator analisis untuk mengidentifikasi makna yang berhubungan dengan pernyataan sebesar $66,30 \%$ dengan kategori tinggi. Kemudian untuk indikator penjelasan konseptual dari suatu peristiwa sebesar 55,20\% dengan kategori sedang, 
indikator interpretasi untuk memahami pengertian sebesar $30,50 \%$ dengan kategori rendah. Selanjutnya indikator evaluasi berupa keterampilan yang memberikan suatu keputusan tentang nilai yang diukur sebesar 30,20\% dengan kategori rendah dan indikator inferensi yaitu keterampilan menjelaskan suatu pengamatan atau pernyataan sebesar 26,20\% dengan kategori rendah.

Rendahnya kemampuan berpikir kritis pada siswa dapat disebabkan oleh beberapa faktor. Belum optimalnya pembelajaran yang mendayagunakan kemampuan berpikir kritis. Menurut Carson (2007) menyatakan meskipun mahasiswa mengetahui suatu konsep tetapi belum tentu mahasiswa dapat mengetahui bagaimana cara menerapkannya. Selain itu, mahasiswa datang perkuliahan sebenarnya tidak membawa pengetahuan yang kosong atau pikiran yang kosong, namun mereka memiliki pengetahuan yang terpotong-potong, sehingga siswa mengalami kesulitan ketika mengaitkan suatu konsep satu sama lain (J. L. Docktor and J. P. Mestre, 2015). Jadi setiap pembelajaran IPA seharusnya tetap melatih mahasiswa untuk berpikir kritis. Sebagaimana Svecova, Rumanova, dan Pavlovicova (2013) dan Chukwuyenum (2013) menyatakan bahwa dalam proses pembelajaran hendaknya menerapkan kegiatan yang melatihkan keterampilan berpikir kritis mahasiswa untuk memberikan kesempatan mengasah keterampilan berpikir kritis mereka.

Hasil penelitian rendahnya kemampuan berpikir kritis mahasiswa untuk aspek interpretasi, evaluasi dan inferensi tentu menjadi perhatian para pendidik. Karena kemampuan berpikir adalah sarana untuk mencapai tujuan pendidikan agar peserta didik mampu memecahkan masalah taraf tingkat tinggi. (Nasution, 2008). Selain itu dengan berpikir kritis akan membantu dalam mengembangkan kemampuan untuk belajar profesional seumur hidup serta dapat menciptakan kemajuan yang lebih besar bagi mahasiswa dalam menganalisis dan pendekatan masalah (Sereni, 2015).

Kemampuan berpikir kritis mahasiswa yang masih tergolong rendah perlu diadakan evaluasi terhadap proses kegiatan pembelajaran di dalam kelas, karena kemampuan berpikir kritis siswa dapat dilatih dan diasah dalam proses pembelajaran. Menurut Tung dan Chang (2009) bahwa untuk mengembangkan kemampuan berpikir kritis dapat melalui pembacaan literatur dengan pilihan teks yang memberikan konteks terpercaya untuk mengembangkan kemampuan kritis dan pemecahan masalah (Shukri, 2015:8).

\section{SIMPULAN DAN SARAN}

Berdasarkan pembahasan dapat disimpulkan bahwa mahasiswa PGSD STKIP Muara bungo memiliki kemampuan berpikir kritis kritis dengan tingkat rata-rata (sedang) sebesar $48,8 \%$, kemudian dengan kriteria rendah $26,7 \%$. Kriteria sangat tinggi sebesar $4,6 \%$, tinggi $11,6 \%$ dan rendah hanya $8,1 \%$.

Kemampuan berpikir kritis mahasiswa PGSD untuk indikator tertinggi yaitu regulasi diri sebesar 68,60\% dengan kategori tinggi, indikator analisis sebesar $66,30 \%$ dengan kategori tinggi, indikator penjelasan sebesar $55,20 \%$ dengan kategori sedang, Indikator interpretasi sebesar $30,50 \%$ dengan kategori rendah, aspek evaluasi sebesar 30,20\% dengan kategori rendah dan indikator inferensi sebesar 26,20\% dengan kategori rendah.

\section{DAFTAR PUSTAKA}

Depdiknas. 2007. Panduan Pengembangan Pembelajaran IPA Terpadu Sekolah Menengah Pertamal Madrasab Tsanawiyah (SMP/MTs). Jakarta Pusat: www.puskur.net

Dharma, Surya. 2008. Kreativitas. Jakarta: Direktorat Tenaga Kependidikan Rektorat Jenderal Peningkatan Mutu Pendidik dan Tenaga kependidikan Departemen Pendidikan Nasional.

Carson, J. (2007). A Problem with Problem Solving: Teaching Thinking Without Teaching Knowledge. The mathematics Educator, (17 (2): 7-14. Diakses dari http://eric.ed.gov/fulltext/EJ841561.pdf.

Facione, Peter A. 2015. Critical Thinking: What It Is and Why It counts. Measured Reasons LLC, Hermosa Beach, CA. Journal. ISBN 13: 978-1-891557-07-1.

Fisher, Alec. 2009. Berpikir Kritis: Sebuah Pengantar. Jakarta: Erlangga.

Hasratuddin. 2010.Meningkatkan Kemampuan Berpikir Kritis Siswa SMP Melalui Pendekatan Matematika Realistik. Universitas Negeri Medan. Jurnal Pendidikan Matematika. Volume 4. No.2 Desember 2010

Hendracipta, Nana. dkk. 2017. Perbedaan Kemampuan Berpikir Kritis Siswa Melalui Penerapan Model Inkuiri Terbimbing Di 
Sekolah Dasar. Jurnal Pendidikan Sekolah Dasar. JPSD Vol. 3 No. 2, September 2017. ISSN 2540-9093. Hal 215-227.

Inggriyani, dkk. 2017. Pengaruh Berpikir Kritis Terhadap Kemampuan Menulis Narasi Siswa Kelas V Di Sekolah Dasar. Jurnal Pendidikan Sekolah Dasar. JPSD Vol. 3 No. 2, September 2017. ISSN 2540-9093. Hal 105116.

Junaidi. 2015. Analisis Kemampuan Berpikir Kritis Matematika Siswa Dengan Menggunakan Graded Response Models Di SMA Negeri 1 Sakti. Jurnal Prodi Pendidikan Matematika FKIP Universitas Jabal Ghafur Sigli. Volume 4. Nomor 1. April 2017. ISSN 2355-0074.

J. L. Docktor and J. P. 2014. Mestre, Synthesis of discipline-based education research in physics. Phys. Rev. Spec. Top. - Phys. Educ. Res., vol. 10, no. 2, pp. 1-58.

Nasution. 2008. Berbagai Pendekatan dalam Proses Belajar Mengajar. Jakarta: BumiAksara.

Quelmalz, Edys S. 1985. Needed: Better Methods for Testing High-Order Thinking Skills. Educational Leadership Article.

Quitadamo, Ian J, Celia L. Faiola, James E. Johnson, and Martha J. Kurtz. 2008. Community based Inquiry Improves Critical Thinking in General Education Biology. Central Washington University, Ellensburg. Article Vol. 7, 327-337.

Rosana. 2012. Menggagas Pendidikan IPA yang Baik Terkait Esensial 21st Century Skills.
Seminar Nasional Pendidikan IPA ke IV, Surabaya 6-7 Desember 2014.

Sereni, Christine. 2015. Teaching Strategies for Critical Thinking Skills. Academic Exchange Quarterly: Saint Leo University. Volume 19, Issue 3

Shukri, Noraini Ahmad. 2015. A Review on Developing Critical Thinking Skills through Literary Texts. Australia : Australian International Academic Centre. Advances in Language and Literary Studies. Vol. 6 No. 2; April 2015.

Svecova, Varelia, Lucia Rumanova dan Gabriela Pavlovicova. 2013. Support of Pupil's Creative Thinking in Mathematical Education. Available www.sciendirect.com Scien direct Procedia-Social and Behavioral Science 116 (2014) 1715-1719.

Tawil, Muh dan Liliasari. 2013. Berpikir Kompleks dan Implementasinya dalam Pembelajaran IPA. Makasar: Badan Penerbit UNM.

Usmaedi. 2017. Menggagas Pembelajaran Hots Pada Anak Usia Sekolah Dasar. Jurnal Pendidikan Sekolah Dasar. JPSD Vol. 3 No. 1, Maret 2017. ISSN 2540-9093. Hal 82-95.

Wahyudi. 2016. Penskoran Politomi Dalam Teori Respon Butir Menggunakan Graded Response Model (GRM). http://repository.unhas.ac.id/handle/1234 56789/20429. Di akses 3 Agustus 2018. 
